\title{
WASTE AS A TYPE OF PUBLIC PROPERTY
}

The purpose of the article is to study waste as a type of public property.

To conduct the research successfully, the author used the following methods of scientific knowledge: logical, historical, systemic-functional, and formally-dogmatic.

As a result of the study, the author forms the opinion that waste can acquire either the status of private or public property depending on a legal regime, which is established for them. At the same time, both statutory regulation and theoretical interpretation of private and public property in Ukraine are disproportionately developed. Thus, the doctrine of private property gained a significantly higher degree of development compared with the doctrine of public property. In this regard, statutory regulation of the legal regime of private property in Ukraine is more elaborated than statutory regulation of the legal regime of public property. As for public property, its doctrine is at the stage of developing. Statutory regulation of the regime of public property in Ukraine has no systemic, holistic character. In this context, it is relevant to study the category "public property", its essence, content and peculiarities, as well as the knowledge of public property through its separate types and, in particular, through waste as a form of public property.

The author believes that waste as a kind of public property is domestic waste, industrial waste, construction and repair waste, hazardous waste, agricultural waste, packaging waste, waste electrical and electronic equipment, waste batteries, radiators and accumulators, medical waste which are owned by the state, population of the ARC and territorial communities. The analysis and study of the features of waste as a public property permits to reconsider the features of public property formed by legal science. The author formulates the common features that are peculiar both to waste and other types of public property. Along with this, the paper shows the specific features that are inherent with waste and not applied to other types of public property.

Conclusions. The origin, change and termination of the status of public property by means of waste, on the one hand, is related to legal facts but, on the other hand, is stipulated by the provisions of Ukrainian legislation. The latter has a number of gaps in the definition of the grounds for the acquisition of public property status by waste and management of republic and municipal wastes. Taking into account this fact, the author proposes a number of amendments to the Law of Ukraine "On Waste", which aimed at specifying the grounds for acquiring ownership of certain types of waste as public property.

Key words: waste, public property, public property features, gaps of waste legislation of Ukraine, grounds for the acquisition of the status of public property, subtypes of public property. 


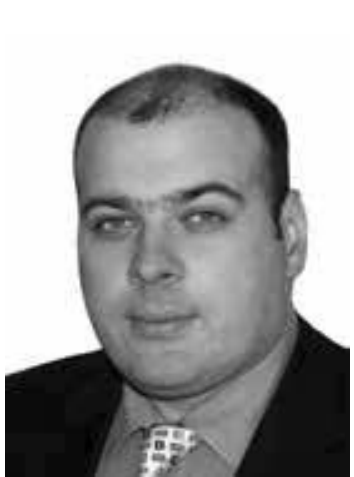

Mykhailo H. Kravchenko Candidate of Juridical Sciences, Senior Research Fellow,

Law Faculty,

Taras Shevchenko

National University of Kyiv

m.g.kravchenko@ukr.net

orcid.org/0000-0002-3909-4599

\section{Introduction}

Legal regulation of a property and property relations arising in this regard is a subject of a large number of researches of domestic and foreign scholars. Such interest to the study of the legal nature of a property is non-accidental. It is connected with the fact that property, the procedure for possession, use and disposal of it is interesting for a significant number of law subjects.

Property can obtain the status of private and public property depending on a legal regime, which is fixed on it. We should mark that both statutory regulation and theoretical interpretation of private and public property in Ukraine are disproportionately developed. For example, the doctrine of private property gained a significantly higher degree of elaboration compared with the doctrine of public property. In this regard, statutory regulation of the legal regime of private property in Ukraine is more developed than the statutory regulation of the legal regime of public property. In our opinion, it is caused, on the one hand, by intense interest of public persons in researches of private-public regulation of origin, changes and termination of the regime of private property and, on the other hand, by the availability of a sufficient number of research studies which permit to formulate a holistic doctrine of private property reflecting in statutory acts, which regulate social relations arising regarding private property. As for public property, its doctrine is at the stage of developeing. Statutory regulation of the regime of public property in Ukraine has no systemic, holistic character. In this context, it is relevant to study the category "public property", its essence, content and peculiarities, as well as the knowledge of public property through its separate types and, in particular, through waste as a form of public property. We believe that the latter aspect of public property research has a profound theoretical value because it permits: to examine a general category through the prism of its individual manifestations (types); to outline the list of features typical for public property in more details; to supplement a doctrine of public property by new provisions. The purpose of the article is to study waste as a separate type of public property. In order to achieve the goal of the research, we identified the following research tasks: 1) to determine the list of features that are particular for waste as for a public property based on the study of its legal nature; 2 ) to determine the grounds for origin, change and termination of the regime of public property by waste; 3 ) to formulate waste list which is among a public property. 
While investigating waste as public property, we have studied and analysed scientific literature of the following focus area:

First, scientific studies directly devoted to the category "public property", its characteristics and types. A.V. Vinnytskyi, V.V. Dzharta, N.Iu. Zadyraka,

O.O. Kravchuk, Ye. V. Petrov $[1 ; 2 ; 3 ; 4 ; 5]$ and others are among researchers who have investigated the topic.

Second, researches related to the institute of public property in the system of administrative law of Ukraine. The investigations of R.S. Melnyk have a pivotal role in this issue $[6 ; 7 ; 8]$.

Third, researches of waste as a public property $[6 ; 7 ; 8]$.

\section{Features of waste as a public property}

In our opinion, a benchmark in the comprehension of waste category is its statutory definition at the legislative level of Ukraine. Thus, Art.1 of the special Law of Ukraine "On Waste" defines waste as any substance, material and object formed in the process of production or consumption, as well as goods (production), which have completely or partially lost their consumer properties and can't be used at the place of their formation or detection and whose owner disposes, intends or must dispose of them by means of utilization or removal [12]. According to the above regulatory definition of the category, waste legislation of Ukraine doesn't consider waste as a property. However, this doesn't mean that waste is not a property. We believe that waste being an object of property right is actually a property, and it can obtain a status either of public or private property depending on a legal regime, which is established towards it. Thus, it is necessary to mark a list of features which will allow separating waste as private property and waste as public property.

We would like to cover a prior issue directly connected with the legal regime of public property, before focusing on the formation of the features of waste as public property. In our opinion, there are two different property regimes: a regime of private property and a regime of public property. The former is regulated by the rules of private law. In Ukraine, these sorts of rules are found, for example, in the Civil Code of Ukraine, Family Code of Ukraine $[13,14]$ and other statutory acts which govern private relations arising due to property's issue. As for the regime of public property, it is regulated by the rules of public law, in particular, of administrative law of Ukraine. The rules of administrative law, which regulate the legal regime of public property, form the institute within a general administrative law of Ukraine [15, c. 50].

Legal regulation of the regime of public property in Ukraine is a quite branched, non-system and has a considerable amount of collisions. We place the Constitution of Ukraine, the Law of Ukraine "On Management of State Property Objects", the Law of Ukraine "On Local Self-Government in Ukraine" [16;17; 18] and others into legal sources which contain the rules of public law and are devoted to the legal regime of public property. The Law of Ukraine "On Waste" is the special one which defines the status of waste as public property [12].

Comparing legal regulation of the regime of private and public property in Ukraine, we can mark that legal regulation of public property doesn't have a statutory act which would be a basic, central act in regulating legal regime of public property. Of course, 
there is the Law of Ukraine "On Management of State Property Objects" [17], but its regulatory influence covers social relations evolving around one of the types of public property, in particular, state property. Legal regulation of the legal regime of republic, municipal property and items of property of the Ukrainian nation is "dispersed" within the legislation of Ukraine that complicates clarification of the order of acquisition, change and termination of the legal regime of republic, municipal and public property and items of property of the Ukrainian people. As for private property, a basic regulation of the legal regime is carried out by virtue of a range of codes including the Civil Code of Ukraine, Commercial Code of Ukraine [13; 14; 19] and a number of other regulatory legal acts which define not only the order of acquisition, change and termination of the regime of private property but also give a wide variety of instruments its holder whereby it has the opportunity to determine the subsequent fate of this kind of property. It is referred to civil contracts, estate and others.

It is also important to draw attention to the fact that exercising a legal regulation of the regime of private property by the Civil Code of Ukraine, the legislation of Ukraine misleads one into believing that civil government is a general part for a legal regulation of any type of property. We try to explain this thesis more specifically. Thus, Art. 190 of the Civil Code of Ukraine [13] has a regulatory definition of the category "property" which is considered as a particular thing, the complex of things as well as property rights or responsibilities. It is also expedient to point out that the Civil Code of Ukraine substituted the Law of Ukraine "On Property" [20] whose rules were devoted not only to private relations in regard to property items but also to public ones. In this context, key issue lies in the fact the Civil Code of Ukraine consolidated a statutory definition of the category "property" as a whole but not the category "private property". This condition has a significant importance because the Civil Code of Ukraine based on private doctrine of property and it is a basic legal source for private law, but not for public. Therefore, it would be worse to consolidate the category "private property" at the regulatory level in Art. 190 of the Civil Code Ukraine. In this respect, it is necessary to turn attention to the lack of category "public property" in the Civil Code of Ukraine. Thus, the category "property" defined in the Civil Code of Ukraine covers both private and public property according to the logic of Ukrainian legislation, and civil regulation is applied not only to private relations but also to public ones in cases which are not directly prohibited by law. We think when solving this issue, it is necessary to take into account the following point: according to the general rule determined in p. 2 Art. 1 of the Civil Code of Ukraine, the civil legislation is not applied to property relations based, in particular, on administrative subordination or other authoritative subordination of one part to another, if another is not established by the law [13]. Thus, juridical basis of the legal regime of public property is public law and, in particular, administrative law. In addition to the above, this doesn't exclude a non-binding application of private law when regulating social relations in respect of public property. If we look at this situation from the point of view of legal regulation of the social relations on waste as public property, then such regulation will have the following form. The special Law of Ukraine "On Waste" specifies: waste list which has a status of public property; grounds for acquisition of ownership of such waste; the rights and obligations of the subjects of public administration regarding such property. 
However, the instruments for disposition of such property, for example, by entering into civil contracts aimed at selling resource valuable waste are regulated by the rules of private law, in particular, by the Civil Code of Ukraine.

Continuing with the determination of features' list of public property, we should rely on the best practices of researchers because, as we have indicated, the legislation of Ukraine doesn't have a statutory definition for the category "public property". Thus, V.M. Pyshchyda defines the following features of public property as follows: 1) it is an object of the property of the Ukrainian people, government property and territorial communities' property; 2) it may be used, in own discretion, by an unlimited number of members of public relations as many times as they see fit or, at least, to count on such use legally; 3 ) it is a means for the implementation of tasks and functions by the subject of public administration, the creation of conditions for the exercise of rights, freedoms, interests by individuals, as well as satisfaction of social needs and interests; 4) its protection is ensured by the rules of public and private law; 5) objects of public property are protected by law, and the legislation of Ukraine arranges liability for impingement on it; 6 ) the general procedure for the implementation of transactions with this property is regulated by branches of private law, in particular civil law; 7) a special procedure (decision) regarding the possession, use and disposal of it is established by the rules of public law and, in particular, administrative law; 8) types of objects of public property, subjects of operational management and procedures for the implementation of rights to it are established by the legislation; 9) the decision on the alienation of such kind of property is taken solely by the subject of public administration, in accordance with the procedure established by the law, and stipulates rendition of an administrative act; 10) similar to the alienation, formation, transformation or termination of the availability of public property is carried out by the exclusive rules defined by the rules of administrative law by subjects of authoritative power; 11) decisions, actions on possession, use and disposal of this property are taken by the subjects of authoritative power on the basis and in the order prescribed by the laws of Ukraine; 12) subjects of authoritative powers are liable for violation of the procedure for possession, use and disposal of this property; 13) decisions, actions or passivity of the subjects of power authorities in relation to the use and disposal of this property may be appealed in a court and extrajudicial order [21, p. 146].

The opinion of R.S. Melnyk towards the features of public property differs somewhat. Thus, the scholar proposes to indicate the following features of public property: 1) it serves for the satisfaction of social, cultural, physical etc. needs of private persons (libraries, recreational parks); 2) it receives public status on the basis of a special legal act (law, regulation, order) or through the direct use in the activities of public authorities; 3 )it is in the possession (management) of public authorities; 4)it is a means aimed at ensuring the functioning of public authorities (administrative building); 5) in some cases, it is a means of activities of public authorities (weapons); 6) it can be completely excluded from civil circulation (fuel for nuclear power plants); 7) it can have both natural (seaside) and artificial origin (car); 8) disposal order of such property is determined by the rules of administrative law [15, p. 40].

In our opinion, such a wide features list of public property is a quite natural. In fact, this category combines a large, in terms of volume, list of various types of property that 
have different physical nature, purpose and legal status, for example, movable or immovable public property, etc. A common thing in these types of property is only a fact that they have the legal regime of public property.

If one compares some features of public property with waste mentioned in scientific literature, we can notice that some of them don't meet the characteristic properties of waste. For example, it is hard to say whether waste serves for the satisfaction of social, cultural, physical and other needs of private persons. However, this does not exclude the fact that this function cannot be performed by other types of public property. Taking into account the abovementioned, it is necessary to distinguish those features of public property that are peculiar to all types of such property and those features that are common to waste as a type of public property.

The general characteristics of public property, which are also peculiar for state, republic and municipal waste, may include as follows:

- its owner is the state, population of the ARC, territorial communities;

- the exercise of owner's powers in relation to such kind of property is

performed indirectly by the latter, but it is delegated to the subjects of public administration: executive authorities; authorities of the ARC; self-government bodies, subjects of delegated powers;

- origin, change and termination of the status of public property by

waste occurs precisely on the basis of the rules of public law and, in particular, of administrative law of Ukraine. At the same time, it may happen that the rules of private law can be optionally involved in the process of legal regulation of the social relations in regard to waste as public property.

Specific characteristics of waste as public property, in our opinion, are as follows:

- waste being public property obliges the subjects of public

administration of Ukraine to manage it. Taking into account this fact, there is a number of public administration functions related to household waste management, industrial waste, waste of construction and repair work, hazardous waste, agricultural production waste, and others.

- the acquisition of waste ownership as public property does not

originate from the voluntary actions (desire) of the subjects of public administration in relation to the acquisition of ownership of such property, but from the duty to be guardian to such public property, to determine its further fate which is defined by the legislation of Ukraine;

- waste is not a means or material basis (base) for the functioning of

the subjects of public administration. On the contrary, such public property requires additional control over it from public administration, for example, through the creation of landfills for certain types of waste, the construction of waste recycling plants, measures to reduce a negative impact of such public property on public health and natural environment.

Consequently, outlined the list of waste features as public property, on the one hand, we specified more precisely those which are typical for all types of public property, but on the other hand, we named those features that characterize the specifics of waste as a form of public property. 


\section{Grounds for origin, change and termination of the regime of public property by means of waste}

Waste gains the status of public property on the basis and in the manner established by the legislation of Ukraine. At the regulatory level, these grounds are specified in the special Law of Ukraine "On Waste" [20]. This Law of Ukraine pays special attention to the grounds for the acquisition of title to state and municipal waste. Thus, according to p. 2 of Art. 9 of the Law of Ukraine "On Waste" [12], a territorial community acquires ownership of waste, which: a) is formed on objects of communal property; b) is in their territory and does not have an owner or its owner is unknown (mismanaged waste). Similar grounds for the acquisition of ownership title are defined for the gain of waste ownership by the state. In accordance with p. 3 Art. 9 of the Law of Ukraine "On Waste", the state holds: a) waste forming on state-owned objects; b) waste which is contained on the territory of Ukraine and does not have an owner or its owner is unknown (mismanaged waste, except municipal waste). At the same time, the above Law of Ukraine mentions nothing about the grounds for the acquisition of the title to Republic's waste that is formed in the territory of the ARC. However, Section III of the Law of Ukraine "On Law, in particular Arts. 19, 20-1, separately defines a range of powers of the ARC government in waste management sphere. It is an obvious point that these powers are not exercised by the ARC authorities in relation to state or communal waste but in relation to republic's waste, which is formed in the territory of the ARC. Therefore, we believe, it is necessary to rectify this situation and to determine the grounds for the acquisition of ownership of republic waste particularly at the level of the Law of Ukraine "On Waste".

It is also should be mentioned, in relation to state waste, the Law of Ukraine "On Waste" makes a significant specification that the Cabinet of Ministers of Ukraine provides management of waste, which is a state-owned property, on behalf of the state. The Law of Ukraine "On Management of State Property Objects" [17] is a legal foundation for this management. However, there is an inconsistency between the mentioned Law of Ukraine and the Law of Ukraine "On Waste" [12] in the part of the determination of the grounds for obtainment of ownership of the objects of state management. We studied this collision in the individual paper [9, p. 64]. Nevertheless, it pays to focus again on the necessity to amend p. 1 Art. 3 of the Law of Ukraine "On Management of State Property Objects" with regard to the specification of the grounds for the acquisition of the right of state ownership to a mismanaged property.

It is also worth mentioning that waste management is also carried out by other entities of public administration, in particular, in relation to Republic's and municipal waste. In this regard, it is possible to mark republic and municipal waste management along with the state waste management. However, the Law of Ukraine "On Waste" [12] does not mention anything about such types of management. It is obvious that this is a disadvantage of the Law of Ukraine "On Waste" [12] which should be improved in this conxt through a statutory consolidation of management mechanism of the republic and municipal waste as public property.

Carrying out waste management, the subjects of public administration of Ukraine determine the further fate of waste as public property. When analyzing waste legislation of Ukraine, it is difficult to define a clear list of tools provided to public administra- 
tion regarding the implementation of such waste management as public property. If one scopes out this problem from a practical point of view, then it is possible to identify two types of such tools: a) public and private. We put the opportunities provided to public administration in relation to waste management as public property, which is carried out by virtue of the rules of public law, to the first type. It is referred to, for example, a decision of a subject of public administration regarding the involvement of private individuals in the collection, treatment and disposal of waste. This kind of involvement (delegation of authority) is executed by order of the subject of public administration, which has an individual character and grants the right to a particular private individual to operations with certain types of waste. In the second group, we will include private law instruments, for example, civil agreements on the alienation of certain types of waste as public property concluded by a subject of public administration and a private individual. For example, buy and sell agreements of resource-valuable waste as public property.

\section{List of waste that has the status of public property}

Defining the list of waste which we refer to public property, we must rely on: a) the provisions of waste legislation of Ukraine and, in particular, of the basic Law of Ukraine "On Waste"; b) the provisions of the science of administrative law since the legislation of Ukraine did not completely regulate the types of waste as public property and, in particular, it did not cover republic waste. Thus, we propose to fill the gaps of Ukrainian legislation in this part by means of the best practices of "public property".

Therefore, guided by the provisions of the basic Law of Ukraine "On Waste" [12], we put state and communal waste into the list of public property. We add republic waste, which even is not mentioned in the Law of Ukraine but actually is formed in the territory of the ARC and managed by the Crimean authorities as subjects of public administration, into the same list.

A somewhat alternative concept of the list of waste as public property can be obtained on the basis of waste classification proposed in the Ukrainian National Waste Management Strategy of Ukraine until 2030 [22]. This strategy offers the following waste classification: household waste, industrial waste, construction waste, hazardous waste, agricultural waste, packaging waste, waste electrical and electronic equipment, waste batteries, radiators and accumulators, medical waste [22].

Consequently, the waste list that we will refer to public property will cover all combinations of state, republic and municipal waste.

\section{Conclusions}

Waste as a type of public property is a domestic waste, industrial waste, waste of construction and repair works, hazardous waste, agricultural waste, packaging waste, waste electrical and electronic equipment, waste batteries, radiators and accumulators, medical waste owned by the state, population of the ARC and territorial communities.

The analysis and research of the features of waste as public property gives an opportunity to reconsider the characteristics of public property formed by legal science. Thus, we attribute the following features that are common to any type of public property to the general features of waste as public property: 1) they are owned by the state, population of the ARC, territorial communities; 2) the exercise of owner's powers with respect to such property is not carried out by the latter directly, but they are delegated to the 
subjects of public administration; 3 ) the origin, change and termination of the status of public property occurs precisely on the basis of the rules of public law and, in particular, of administrative law. In addition, specific features that characterize peculiarities of this type of public property can be marked, in particular: waste obliges the subjects of public administration of Ukraine to manage it; ownership rights to the waste origin not from the volitional actions of the latter, but from the duty of the subjects of public administration take to charge of such public property. Waste is not a material basis for the functioning of public administration, but, conversely, it requires the use of a number of cost measures to limit its negative impact on a man and the environment.

The origin, change and termination of a status of public property by means of waste, on the one hand, is related to legal facts, and on the other hand, is stipulated by the provisions of the Ukrainian legislation. The latter has a number of gaps in a determination of the grounds for the acquisition of the status of public property by waste and the management of republic and communal wastes. Taking into account these facts, we propose to amend the Law of Ukraine "On Waste" and determine the grounds for the acquisition of ownership of republic waste as well as to determine the mechanism of management of republic and communal wastes in Ukraine.

\section{Bibliography:}

1. Винницкий А.В. Публичная собственность. М.: Статут, 2013. 732 с.

2. Джарти В.В. Адміністративно-правові засади управління об'єктами державної власності в Україні : автореф. дис. ... канд. юрид. наук. Запоріжжя, 2014. 16 с.

3. Задирака Н.Ю. Місце та призначення інституту публічного майна в системі загального адміністративного права. Підприємництво, господарство і право. 2017. № 9. С. 125-128.

4. Кравчук О.О. Адміністративно-правове регулювання управління державною власністю в Україні : дис. ... д-ра юрид. наук : К, 2014. 450 с.

5. Петров С. В. Адміністративно-господарське право як підгалузь адміністративного права України : дис. ... д-ра юрид. наук. : Х, 2012. 415 с.

6. Мельник Р.С. Система адміністративного права України : дис. ... д-ра юрид. наук : X., $2010.415 \mathrm{c}$.

7. Мельник Р.С., Бевзенко В.М. Загальне адміністративне право: Навчальний посібник / За заг. ред. Р.С. Мельника. К.: Ваіте, 2014. 376 с.

8. 100 ответов на 100 вопросов по Общему административному праву: учеб. пособ. под ред. Р.С. Мельника. Киев: Юринком Интер, 2017. 240 с.

9. Кравченко М.Г. Чи є побутові відходи в Україні майном? Позиція законодавства України та законодавства Європейського Союзу. Журнал східноєвропейського права. 2017. № 43. С. 58-66.

10. Кравченко М.Г. Нормативне закріплення системи джерел адміністративного права України: проблеми та перспективи. Актуальні питання розвитку юридичної науки та практики: матеріали Міжнародної науково-практичної конференції студентів, аспірантів та молодих вчених, присвяченої Дню науки юридичного факультету 18 травня 2018. К, 2018. C. 281-282.

11. Відходи - не сміття. URL: https://blog.liga.net/user/ikremenovskaya/article/26602.

12. Про відходи: Закон України від 05.04.1998 p. URL: http://zakon.rada.gov.ua/laws/ show/187/98-\%D0\%B2\%D1\%80.

13. Цивільний кодекс України від 16.01.2003 p. URL: http://zakon.rada.gov.ua/laws/ show/435-15. 
14. Сімейний кодекс України від 10.01.2002 p. URL: http://zakon.rada.gov.ua/laws/ show/2947-14.

15. Мельник Р.С., Мосьондз С.О. Адміністративне право України (у схемах та коментарях): навч. посібник. за ред. Р.С. Мельника. К.: Юрінком Інтер, 2017. 344 с.

16. Конституція України від 28.06 .1996 p. URL: http://zakon2.rada.gov.ua/laws/ show/254к/96-вр.

17. Про управління об’єктами державної власності: Закон України від 21.09.2006 p. URL: http://zakon.rada.gov.ua/laws/show/185-16.

18. Про місцеве самоврядування в Україні: Закон України від 21.05.1997 p. URL: http://zakon5.rada.gov.ua/laws/show/280/97-вр.

19. Господарський кодекс України від 16.01.2003 p. URL: http://zakon.rada.gov.ua/laws/ show/436-15.

20. Про власність : Закон України від 07.02.1991p. URL: http://zakon.rada.gov.ua/laws/ show/697-12.

21. Пищида Т.В. Публічне майно як об'єкт публічно-правового спору в адміністративних судах. Науковий вісник Міжнародного гуманітарного університету. Сер.: Юриспруденція. 2015. № 17. Том 1. С. 145-148.

22. Про схвалення Національної стратегії управління відходами в Україні до 2030 р.: Розпорядження Кабінету Міністрів України від 08.11.2017 р. № 820-p. URL: http://zakon5.rada.gov.ua/laws/show/820-2017-\%D1\%80.

\section{References:}

1. Vinnitskiy A.V. (2013) Publichnaya sobstvennost' [Public property]. Moscow: Statut. 732 p. [in Russian].

2. Dzharty V.V. (2014) Administratyvno-pravovi zasady upravlinnya ob"yektamy derzhavnoyi vlasnosti v Ukrayini [Administrative and Legal Principles of Management of StateOwned Objects in Ukraine]. (the dissertation author's abstract of the candidate of legal sciences). Zaporizhzhya. 16 p. [in Ukrainian].

3. Zadyraka N.Yu. (2017) Mistse ta pryznachennya instytutu publichnoho mayna v systemi zahal'noho administratyvnoho prava.[ Place and appointment of the institution of public property in the system of general administrative law] Pidpryyemnytstvo, hospodarstvo i pravo. no. 9. pp. 125-128. [in Ukrainian].

4. Kravchuk O.O. (2014)Administratyvno-pravove rehulyuvannya upravlinnya derzhavnoyu vlasnistyu v Ukrayini. [Administrative and Legal Regulation of State Property Management in Ukraine]. (Thesis of Doctor of Law). Kyiv. 450 p. [in Ukrainian].

5. Petrov Ye. V. Administratyvno-hospodars'ke pravo yak pidhaluz' administratyvnoho prava Ukrayiny (2012) [Administrative and Commercial Law as a Subdivision of Administrative Law of Ukraine]. (Thesis of Doctor of Law). Kharkiv. 415 p. [in Ukrainian].

6. Mel'nyk R.S. Systema administratyvnoho prava Ukrayiny (2010) [The system of administrative law of Ukraine]. (Thesis of Doctor of Law). Kharkiv. 415 p. [in Ukrainian].

7. Mel'nyk R.S., Bevzenko V.M. Zahal'ne administratyvne pravo (2014) [General administrative law] Navchal'nyy posibnyk. Kyiv: Vaite. 376 p. [in Ukrainian].

8. 100 otvetov na 100 voprosov po Obshchemu administrativnomu pravu (2017) [100 answers to 100 questions on general administrative law]. uchebnoye posobiye. pod red. R.S. Mel'nika. Kyiv. Yurinkom Inter. 240 p. [in Russian].

9. Kravchenko M.H. (2017) Chy ye pobutovi vidkhody v Ukrayini maynom? Pozytsiya zakonodavstva Ukrayiny ta zakonodavstva Yevropeys'koho Soyuzu. [Is domestic waste in Ukraine property? The position of the legislation of Ukraine and the legislation of the European Union.] Zhurnal skhidnoyevropeys'koho prava. no.43. pp. 58-66. [in Ukrainian]. 
10. Kravchenko M.H. (2018) Normatyvne zakriplennya systemy dzherel administratyvnoho prava Ukrayiny: problemy ta perspektyvy. (2018) [Normative consolidation of the system of sources of administrative law in Ukraine: problems and perspectives.] Aktual'ni pytannya rozvytku yurydychnoyi nauky ta praktyky: materialy Mizhnarodnoyi naukovo-praktychnoyi konferentsiyi studentiv, aspirantiv ta molodykh vchenykh, prysvyachenoyi Dnyu nauky yurydychnoho fakul'tetu 18 travnya 2018 roky. Kyiv. pp. 281-282. [in Ukrainian].

11. Vidkhody - ne smittya (2017) [Waste - not garbage]. Retrieved from: https://blog.liga.net/ user/ikremenovskaya/article/26602. [in Ukrainian].

12. Pro vidkhody(1998)[On Waste]: Zakon Ukrayiny. Retrieved from: http://zakon.rada.gov.ua/ laws/show/187/98-\%D0\%B2\%D1\%80. [in Ukrainian].

13. Tsyvil'nyy kodeks Ukrayiny (2003) [The Civil Code of Ukraine]. Retrieved from: http://zakon.rada.gov.ua/laws/show/435-15. [in Ukrainian].

14. Simeynyy kodeks Ukrayiny (2002) [The Family Code of Ukraine]. Retrieved from: http://zakon.rada.gov.ua/laws/show/2947-14. [in Ukrainian].

15. Mel'nyk R.S., Mos'ondz S.O. (2017) Administratyvne pravo Ukrayiny (u skhemakh ta komentaryakh) [Administrative law of Ukraine (in the schemes and comments)]: navchal'nyy posibnyk. za red. R.S. Mel'nyka. Kyiv. Yurinkom Inter. 344p. [in Ukrainian].

16. Konstytutsiya Ukrayiny (1996) [Constitution of Ukraine]. Retrieved from: http://zakon2.rada.gov.ua/laws/show/254к/96-вp. [in Ukrainian].

17. Pro upravlinnya ob"yektamy derzhavnoyi vlasnosti (2016) [About management of objects of state property]: Zakon Ukrayiny. Retrieved from: http://zakon.rada.gov.ua/laws/show/185-16. [in Ukrainian].

18. Pro mistseve samovryaduvannya v Ukrayini (1997) [On Local Self-Government in Ukraine]: Zakon Ukrayiny. Retrieved from: http://zakon5.rada.gov.ua/laws/show/280/97-вp. [in Ukrainian].

19. Hospodars'kyy kodeks Ukrayiny (2003) [The Commercial Code of Ukraine]. Retrieved from: http://zakon.rada.gov.ua/laws/show/436-15. [in Ukrainian].

20. Pro vlasnist' (1991) [About Property]: Zakon Ukrayiny. Retrieved from: http://zakon.rada.gov.ua/laws/show/697-12. [in Ukrainian].

21. Pyshchyda T.V. (2017) Publichne mayno yak ob'yekt publichno-pravovoho sporu v administratyvnykh sudakh [Public property as an object of public-law dispute in administrative courts]. Naukovyy visnyk Mizhnarodnoho humanitarnoho universytetu. Yurysprudentsiya. no.17. pp.145-148. [in Ukrainian].

22. Pro skhvalennya Natsional'noyi stratehiyi upravlinnya vidkhodamy $v$ Ukrayini do 2030 r.[On Approval of the National Strategy for Waste Management in Ukraine until 2030]: Rozporyadzhennya Kabinetu Ministriv Ukrayiny. Retrieved from: http://zakon5.rada.gov.ua/ laws/show/820-2017-\%D1\%80. [in Ukrainian]. 


\title{
ОСОБЛИВЕ АДМІНІСТРАТИВНЕ ПРАВО
}

\section{ВІДХОДИ ЯК ВИД ПУБЛІЧНОГО МАЙНА}

\author{
Кравченко Михайло Георгійович, \\ кандидат юридичних наук, \\ старший науковий співробітник юридичного факультету \\ Київського національного університету \\ імені Тараса Шевченка \\ m.g.kravchenko@ukr.net \\ orcid.org/0000-0002-3909-4599
}

Метою статті є дослідженню відходів як виду публічного майна.

Для успішного проведення дослідження, автором, використані наступніметоди наукового пізнання: логічний, історичний, системно-функиіональний, формально-догматичний.

В результаті дослідження автор приходить висновку про те, щзо відходи в залежності від правового режиму, який встановлюється щчодо них можуть набувати статус або приватного, або публічного майна. При цьому, як нормативне регулювання, так і теоретичне осмислення приватного та публічного майна в Украӥні розвинуті непропориійно. Так, вчення про приватне майно отримало значно вищий ступінь розвитку у порівнянні із вченням про публічне майно. У зв'язку із ичим нормативне регулювання правового режиму приватного майна в Україні знаходиться на значно вищому рівні ніж правове регулювання правового режиму публічного майна. Що ж стосується публічного майна, то вчення про нього знаходиться на стадії формування. Нормативне регулювання режиму публічного майна в Україні не має системного, цілісного характеру. У зв'язку із ичи актуальними є подальші дослідження як самої категорії «публічне майно», ї̈ сутності, змісту та властивих їй ознак, так $і$ пізнання публічного майна через окремі його види, а зокрема через відходи як вид публічного майна.

Автор вважає, щчо відходами як видом публічного майна є побутові відходи, промислові відходи, відходи будівельно-ремонтних робіт, небезпечні відходи, відходи виробництва продукиії сільського-господарства, відходи упаковки, відходи електричного та електронного обладнання, відпрацьовані батарейки, батареї та акумулятори, медичні відходи власником, яких є держава, населення АРК та територіальні громади.

Аналіз $i$ дослідження ознак відходів як публічного майна дає можливість переосмислити сформовані юридичною наукою ознаки публічного майна. Автором визначені загальні ознаки, які властиві як відходам, так і іншим видам публічного майна. Поряд із цим названі специфічні ознаки, які властиві лише відходам $і$ не розповсюджуються на інші види публічного майна.

Висновки. Виникнення, зміна та припинення відходами статусу публічного майна з одного боку, пов'язана із юридичними фактами, а з іншого, обумовлюється положеннямизаконодавства Украӥни. Останнємаєнизкупрогалин, в частині визначення підстав набуття відходами статусу публічного майна та здійснення управління республіканськими та комунальними відходами. Враховуючи це автором запропоновано низку змін до Закону Украӥни «Про відходи», які спрямовані на конкретизачію підстав набуття права власності на окремі види відходів як публічного майна.

Ключові слова: відходи, публічне майно, ознаки публічного майна, пропалини законодавства України про відходи, підстави набуття статусу публічного майна, підвиди публічного майна. 